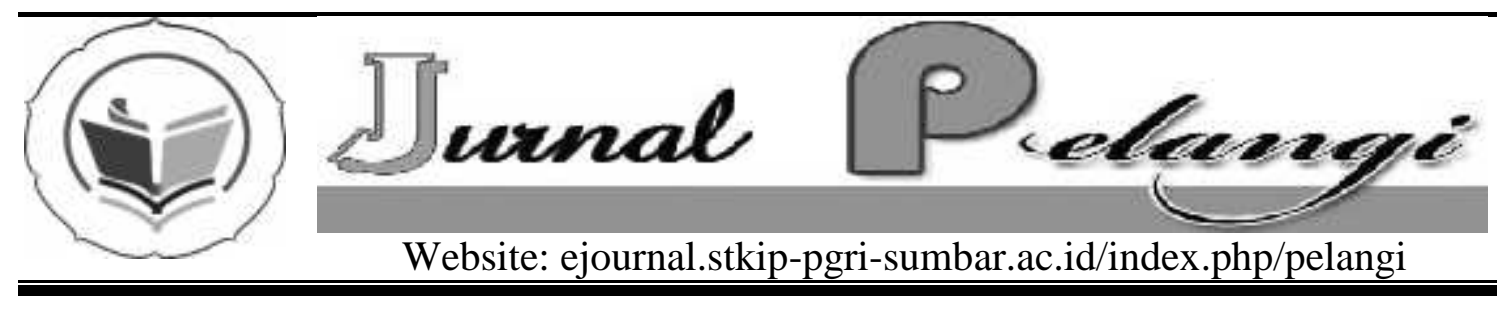

\title{
PENGEMBANGAN INSTRUMEN PENILAIAN PSIKOMOTOR PADA MATERI SISTEM PENCERNAAN KELAS XI SMA
}

\author{
Ade Dewi Maharani ${ }^{1)}$ Zulfitri Aima ${ }^{2)}$ \\ ${ }^{1)}$ Program Studi Pendidikan Biologi STKIP PGRI Sumatera Barat \\ ${ }^{2)}$ Program Studi Pendidikan Matematika STKIP PGRI Sumatera Barat \\ adedewimaharani@yahoo.co.id
}

INFO ARTIKEL

Diterima : 28/02/2014

Disetujui : 30/05/2014

Kata Kunci:

Penilaian psikomotor, instrumen penilaian kinerja (performance), instrumen penilaian produk, instrumen penilaian proyek, validitas, praktikalitas.

\begin{abstract}
Abstrak
Hasil supervisi dan evaluasi keterlaksanaan KTSP tahun 2009 ditemukan beberapa hal yang menjadi kesulitan bagi guru dalam menyusun perangkat penilaian psikomotor. Kesulitankesulitan yang dimaksud antara lain cara menentukan kata kerja operasional sesuai dengan tingkat kompetensi pada ranah psikomotor, teknik mengembangkan indikator pencapaian dalam ranah psikomotor, strategi menyiapkan perangkat penilaian dan bahan ujian sesuai karakteristik aspek psikomotor dan cara melaksanakan penilaian secara objektif sehingga diperlukan pengembangan instrument penilaian ranah psikomotor yang valid dan praktis pada materi sistem pencernaan. Penelitian ini merupakan penelitian pengembangan (research for the development) yang menggunakan model Fenrich, yaitu analysis (analisis), planning (perencanaan), design (perancangan), development (pengembangan), implementation evalution (implementasi), evalution (evaluasi) dan revision (revisi). Tahap implementation dan evalution tidak dilakukan. Data validasi diperoleh dari lembar validasi yang diisi oleh pakar dan praktis diperoleh dari angket yang diisi oleh praktisi. Validitas yang diukur mencakup aspek materi, aspek konstruksi instrument, dan aspek bahasa. Praktikalitas mengukur kemudahan merancang dan menggunakan instrumen penilaian psikomotor yang dikembangkan. Data dianalisis dengan analisis deskriptif berupa persentase. Instrumen penilaian ranah psikomotor pada materi sistem pencernaan dirancang berupa penilaian kinerja, produk, proyek yang dilengkapi dengan rubrik penilaian dari masing-masing instrumen. Hasil validasi instrumen penilaian psikomotor dikategorikan sangat valid dengan nilai rata-rata untuk instrumen penilaian kinerja (performance) 90,3\%, instrumen penilaian produk 92,2\%, dan insrumen penilaian proyek 97,4\%. Sedangkan tingkat
\end{abstract}


kepraktisan instrumen penilaian psikomotor dikategorikan praktis dengan nilai rata-rata $72,23 \%$.

\begin{abstract}
The result of supervision and evaluation of KTSP 2009 finds some things that become difficulties for teachers in managing the psychomotor assessment tools. Difficulties referred to, among others, how to determine the operational verb in accordance with the level of competence in psychomotor, techniques to develop indicators of achievement in the field of psychomotor, assessment tools and strategies to prepare the appropriate exam materials related to characteristics of psychomotor aspects and how to carry out an objective assessment, so that the necessary development of assessment instruments psychomotor valid and practical in the material of digestive system. This research is a development (research for the development) that uses model Fenrich, namely analysis (analysis), planning (planning), design (design), development (development), implementation evalution (implementation), evalution (evaluation) and revision (revision) Implementationdan evalution phase was not conducted. Validation of data was obtained from the validation sheet filled out by experts and practical that were obtained from a questionnaire completed by the practitioner. Validity measured includes material aspects, aspects of instrument construction, and aspects of the language. The practicalities of measuring the ease of designing and using assessment instruments psychomotor developed. Data were analyzed with descriptive analysis in the form persentage.Instrument of psychomotor assessment on the material digestive system is designed in the form of performance assessment, products, projects which are completed with assessment rubrics of each instrument. The tests of psychomotor assessment instruments are categorized as very valid with an average value for the performance appraisal instrument (performance) i.e. 90.3\%, 92.2\% is product assessment instruments, and project assesment insrument i.e.97.4\%. While the level of psychomotor assessment instruments is categorized practicality with an average value i.e $72.23 \%$.
\end{abstract}

Keywords:

psychomotor

assessment,

psychomotor

assessment

performance, product assessment

instruments, project

assesment

insrument,

validity, practicality

\section{PENDAHULUAN}

Salah satu kebijakan pemerintah di bidang pendidikan adalah rumusan Standar Nasional Pendidikan (SNP) yang ditetapkan melalui Peraturan Pemerintah Nomor 19 Tahun 2005 tentang Standar Nasional Pendidikan, Peraturan pemerintah (PP) Nomor 19
Tahun 2005 Pasal 25 ayat 4 menyatakan bahwa kompetensi lulusan mencakup sikap, pengetahuan, dan keterampilan dan Peraturan Menteri Pendidikan Nasional (Permendiknas) Nomor 20 Tahun 2007 menyebutkan bahwa salah satu prinsip penilaian adalah menyeluruh dan berkesinambungan. Hal ini berarti 
pembelajaran dan penilaian harus mengembangkan kompetensi peserta didik yang berhubungan dengan ranah afektif, kognitif, dan psikomotor. Kebijakan ini menuntun terjadinya perubahan sistem penilaian. Perubahan sistem penilaian yang dimaksud adalah penilaian dengan acuan normal ke penilaian yang menggunakan acuan kriteria atau standar yaitu aspek yang menunjukkan seberapa kompeten peserta didik menguasai materi yang telah diajarkan. Dalam kurikulum 2006 menuntut guru untuk melakukan penilaian bukan hanya pada ranah kognitif tapi juga pada ranah psikomotor dan ranah afektif. Untuk dapat merancang dan melaksanakan penilaian psikomotor yang sesuai dengan standar penilaian, guru harus memiliki pengetahuan, pemahaman, dan kemampuan yang memadai dalam mengembangkan perangkat penilaian psikomotor. Penilaian psikomotor terdiri atas penilaian kinerja (performance), penilaian produk, penilian proyek, dan penilaian portopolio.

\section{Penilaian Kinerja (Performance)}

Menurut Trespeces (1999 dalam Depdiknas, 2003) unjuk kerja atau performance assessment adalah berbagai macam tugas dan situasi dimana peserta tes diminta untuk mendemonstrasikan pemahaman dan pengaplikasian pengetahuan yang mendalam, serta keterampilan di dalam berbagai macam konteks sesuai dengan kriteria yang diinginkan. Begitu pula menurut Anwar (2009: 89) bahwa kinerja mengacu pada upaya melakukan sesuatu yang mempraktikkan pengalaman tertentu sehingga prosesnya dapat dikontrol. Penilaian ini dilakukan dengan cara mengamati kegiatan peserta didik dalam melakukan sesuatu, seperti praktikum, praktik sholat, olahraga, kemampuan berdiskusi, presentasi, bernyanyi, bertukang dan lain sebagainya.

Karakteristik penilaian unjuk kerja menurut Kubyszyn dan Borich (2003 dalam Anwar, 2009) adalah: a) tes kinerja bersifat langsung (direct measures), contohnya dalam dunia olah raga dan seni. Seorang yang terampil dalam bermain bola basket, dapat diketahui setelah ia diminta melakukan demonstrasi memainkan bola basket sesuai dengan ketentuan yang telah dirancang, dan hasilnya langsung dapat diamati. Begitu juga seorang seniman lukis, tenaga labor, tenaga komputer dan lain sebagainya. b) tes kinerja merupakan stimulus terhadap dunia nyata (the real world), misalnya tes ini dilakukan ketika memasuki dunia kerja, dimana seorang calon tenaga kerja tidak langsung direkrut, tetapi membutuhkan beberapa waktu untuk mengetahui kemampuan kerjanya sesuai dengan standar-standar yang ditetapkan. c) tes kinerja juga mengobservasi pencapai hasil belajar, mental, dan sikap. Artinya ketika seorang telah memasuki dunia kerjanya, pada saat itu akan diamati bagaimana mental dan sikapnya terhadap pekerjaan itu. d) tes kinerja dapat menilai proses, produk atau kedua-duanya. Penilaian proses yang dapat dilakukan kepada peserta didik misalnya dalam proses membaca buku teks bahasa Inggris. Dalam hal ini kesalahan pada setiap kata atau kalimat dicatat, lalu diberi skor tertentu. Demikian juga halnya di labor, di bengkel, termasuk dalam pengoperasian perangkat komputer.

Hal-hal yang harus diperhatikan melakukan penilaian unjuk kerja menurut Popham (1995) adalah: a) generability, artinya apakah kinerja peserta tes dalam melakukan tugas yang diberikan sudah memadai untuk digeneralisasikan pada tugas-tugas yang 
lain? Semakin dapat digeneralisasikan kepada tugas-tugas yang diberikan dalam rangka penilaian kinerja tersebut atau semakin dapat dibandingkan dengan tugas yang lainnya maka semakin baik tugas tersebut, (b) sudah mengukur authenticyty, artinya apakah tugas yang diberikan sudah serupa dengan apa yang sering dihadapinya dalam praktek kehidupan sehari-hari, (c) multiple foci, artinya apakah tugas yang diberikan kepada peserta didik satu kemampuan-kemampuan yang diinginkan, (d) teachability, artinya tugas yang diberikan merupakan tugas yang hasilnya semakin baik karena adanya usaha mengajar di kelas, (e) fairness, artinya apakah tugas yang diberikan sudah adil untuk semua peserta didik, (f) feasibility, artinya apakah-tugas-tugas yang diberikan dalampenilaian kinerja memang relevan untuk dilaksanakan mengingat faktorfaktor seperti biaya, ruangan, waktu dan peralatan, (g) scorability, artinya apakah tugas yang diberikan nanti dapat di skor dengan akurat dan reliabel.

Pengamatan unjuk kerja perlu dilakukan dalam berbagai konteks untuk menetapkan tingkat pencapaian kemampuan tertentu. Untuk menilai kemampuan berbicara peserta didik, misalnya dilakukan pengamatan atau observasi berbicara yang beragam, seperti: diskusi dalam kelompok kecil, berpidato, bercerita, dan melakukan wawancara. Dengan demikian, gambaran kemampuan peserta didik akan lebih utuh. Untuk mengamati unjuk kerja peserta didik dapat menggunakan alat atau instrumen berikut: a) daftar Cek (Check-list), b) skala bertingkat (Rating Scale), c) rekaman anekdot (anecdotal record).

\section{Penilaian Produk}

Penilaian hasil kerja siswa adalah penilaian terhadap keterampilan siswa dalam membuat suatu produk benda tertentu dan kualitas produk tersebut. Dalam penilaian hasil kerja siswa terdapat dua konsep penilaian, yaitu (a) penilaian tentang pemilihan dan cara penggunaan alat serta prosedur kerja siswa, (b) penilaian tentang kualitas teknis maupun estetika hasil karya/kerja siswa. Penilaian hasil kerja bertujuan (Depdiknas, 2003) untuk: (a) menilai penguasaan keterampilan siswa yang diperlukan sebelum mempelajari keterampilan berikutnya, (b) menilai tingkat kompetensi yang sudah dikuasai siswa pada setiap akhir jenjang/kelas di sekolah kejuruan, (c) menilai keterampilan siswa yang akan memasuki institusi pendidikan kejuruan. Aspek yang dinilai dari suatu produk antara lain: (1) tahap persiapan, pemilihan dan cara penggunaan alat, (2) tahap proses/produksi, prosedur kerja. (3) tahap akhir/hasil (Anwar, 2009).

\section{Penilaian Proyek}

Penilaian proyek merupakan penilaian terhadap kegiatan berupa hasil observasi atau penelitian-penelitian sederhana yang dilakukan siswa, baik di lingkungan sekitar sekolah maupun di lingkungan masyarakat. Pada prinsipnya penilaian proyek bertujuan untuk mengetahui sejauhmana peserta didik mampu mengaplikasikan ilmu yang diperoleh di dalam kelas dengan kenyataan yang ada di lapangan, sekaligus menuntut kemampuan berinteraksi dengan lingkungan sekitarnya. Dalam perencanaan penilaian proyek terdapat tiga hal yang perlu dipertimbangkan (Depdiknas, 2003), yaitu: a) kemampuan pengelolaan, jika siswa diberi kebebasan yang luas, mereka akan mendapatkan kesulitan dalam memilih topik yang tepat. Mereka mungkin memilih topik yang terlalu luas sehingga sedikit informasi yang dapat 
ditemukan. mereka mungkin juga kurang tepat untuk memperkirakan waktu pengumpulan data dan penulisan laporan. b) relevansi, guru harus mempertimbangkan pengetahuan, keterampilan, dan pemahaman pada pembelajaran agar proyek dapat dijadikan sebagai sumber bukti. c) keaslian, guru perlu mempertimbangkan seberapa besar petunjuk atau dukungan yang diberikan pada siswa.

Aspek yang dinilai dalam penilaian proyek ditentukan oleh guru berdasarkan indikator dan kompetensi dasar yang diharapkan dimiliki siswa. Misalnya kemapuan membuat perencanaan, mengumpulkan data, mengolah, menyajikan dan melaporkan data.

\section{Penilaian Portopolio}

Portopolio dapat diartikan sebagai wujud benda fisik berupa sebuah bundel yang berisi kumpulan dokumentasi hasil kerja siswa dalam jangka waktu tertentu. Menurut Popham (1995) mengemukakan bahwa portopolio adalah kumpulan sistematis tentang hasil pekerjaan seseorang. Budimansyah (2007) mengemukakan portopolio diartikan sebagai wujud benda fisik. Portopolio berupa bundel yang berisikan kumpulan atau dokumentasi hasil pekerjaan peserta didik.

Penilaian portofolio dapat memberi kesempatan kepada peserta didik dan guru untuk menelaah bagaimana pekerjaan, yang terutama pekerjaan baru yang sedang atau telah mereka selesaikan. Beberapa keuntungan penilaian portofolio (Surapranata dan Hatta, 2007) antara lain; (a) mampu merefleksikan perubahan penting dalam proses kemampuan intelektual peserta didik dari waktu ke waktu; (b) menunjukkan prestasi akademik dan memotret kompetensi peserta didik; (c) mampu memfokuskan pada kepentingan dan proses kemampuan belajar-mengajar serta menginformasikan pengajaran praktis tentang kelebihan dan kekurangan peserta didik.

Portofolio dalam penilaian di kelas dapat digunakan untuk mencapai beberapa tujuan yaitu: (a) Menghargai perkembangan yang dialami peserta didik; (b) Mendokumentasikan proses pembelajaran yang berlangsung; (c) Menberi perhatian pada prestasi kerja peserta didik yang terbaik; (d) Merefleksikan kesanggupan mengambil resiko dan melakukan eksperimentasi; (e) Meningkatkan efektivitas proses pengajaran; (f) Bertukar informasi dengan orang tua/ wali peserta didik dan guru lain; (g) Membina dan mempercepat pertumbuhan konsep diri positif pada peserta didik; (h) Meningkatkan kemampuan melakukan refleksi diri; (i) Membantu peserta didik dalam merumuskan tujuan (Surapranata dan Hatta, 2007).

Hasil wawancara dengan tiga orang guru SMA di kota Padang menyatakan bahwa pelaksanaan sistem penilaian selama ini, guru belum mampu melaksanakan dengan baik tuntutan penilaian kurikulum 2006 karena penilaian yang dilakukan masih berupa tes tertulis. Penilaian ini hanya melihat ranah kognitif dan belum menilai proses pembelajaran yang dialami peserta didik. Penilaian masih berfokus pada ranah kognitif peserta didik dan belum mengikutkan ranah afektif dan psikomotor secara bersamaan. Pada ranah afektif guru hanya melihat peserta didik mengikuti pelajaran atau tidak, mengabaikan sikap, motivasi, dan minat peserta didik dalam pembelajaran. Sedangkan pada ranah psikomotor guru hanya melihat peserta didik mengerjakan latihan dan tugas 
saja, bagaimana peserta didik mengerjakan latihan dan tugas tidak dinilai. Jadi, penilaian yang dilakukan pada akhir pembelajaran saja akhirnya menyebabkan perkembangan belajar peserta didik tidak terpantau dengan baik. Hal ini sesuai dengan pendapat Wija (2004 dalam Muslich, 2009) yang menyatakan bahwa sebagian guru masih menghadapi kesulitan dalam proses penilaian hasil belajar siswa.

Hasil supervisi dan evaluasi keterlaksanaan KTSP tahun 2009 yang dilakukan depdiknas ditemukan beberapa hal yang menjadi kesulitan bagi guru dalam menyusun perangkat penilaian psikomotor. Kesulitankesulitan yang dimaksud antara lain cara menentukan kata kerja operasional sesuai dengan tingkat kompetensi pada ranah psikomotor, teknik mengembangkan indikator pencapaian dalam ranah psikomotor, strategi menyiapkan perangkat penilaian dan bahan ujian sesuai karakteristik aspek psikomotor dan cara melaksanakan penilaian secara objektif. Selain itu, guru belum terbiasa dan kurang memahami bagaimana cara menilai ranah psikomotor yang dituntut dalam kurikulum 2006. Guru bingung bagaimana memberikan skor pada setiap indikator penilaian yang diminta sehingga guru lebih memilih tidak melakukan penilaian untuk ranah psikomotor. Hal ini juga dikarenakan guru mengalami kesulitan menemukan literatur yang dapat dipedomani dalam melaksanakan penilaian berbasis kelas bagi bidang studinya. Literatur-literatur yang ada hanya memberikan penjelasan bagaimana meningkatkan efisiensi assesmen, seperti bagaimana menyusun pertanyaan pilihan ganda dan mengolah hasil tes dengan perhitungan statistik.

\section{METODE}

Penelitian ini merupakan penelitian pengembangan karena pada penelitian ini dikembangkan instrumen penilaian psikomotor pada mata pelajaran biologi kelas XI SMA. Model pengembangan yang digunakan adalah model yang dikembangkan oleh Fenrich (1997) dalam Nur (2006:6), yaitu analysis (analisis), planning (perencanaan), design (perancangan), development (pengembangan), implementation (implementasi), evalution (evaluasi) dan revision (revisi).

\section{Produksi Instrumen Penilaian Psikomotor \\ Penelitian diawali dengan} merancang instrument penilaian psikomotor pada materi sistem pencernaan. Langkah kerjanya adalah Pertama, menganalisis konsep-konsep penilaian khususnya penilaian psikomotor, menganalisis kurikulum mata pelajaran biologi kelas XI SMA, menganalisis buku-buku teks biologi kelas XI dan menganalisis peserta didik. Kedua, merancang (SK, KD, dan indikator) instrumen penilaian psikomotor hingga menghasilkan indikator dan kisi-kisi instrumen yang akan dikembangkan. Berdasarkan indikator dan kisi-kisi instrument dibuat instrument penilaian psikomotor berupa penilaian kinerja, penilaian produk, dan penilaian proyek yang masingmasingnya dilengkapi dengan pedoman penilaian.

\section{Uji Validitas dan Praktikalitas Instrumen Penilaian Psikomotor}

Uji validitas dilakukan oleh ahli/pakar. Perbaikan dilakukan dengan membuang, memperbaiki dan menambahkan bagian-bagian penting sesuai dengan saran dari validator. Selanjutnya, dilakukan uji praktikalitas 
oleh guru di SMA Negeri 3 Padang dan SMA Negeri 10 Padang. Tahap ini bertujuan untuk melihat kepraktisan instrument penilaian yang telah dibuat.

\section{HASIL DAN PEMBAHASAN}

\section{Produksi Instrumen Penilaian Psikomotor}

Uji praktikalitas dilakukan oleh guru di SMA Negeri 3 Padang dan SMA Negeri 10 Padang. Penelitian ini menghasilkan instrument penilaian psikomotor yang akan digunakan dalam pembelajaran biologi kelas XI SMA. Produk penelitian ini ditampilkan pada tabel 1.

\section{Uji Validitas dan Praktikalitas Instrumen Psikomotor}

Data validitas isi dan validitas konstruk disajikan pada tabel 2. Uji praktikalitas instrumen penilaian psikomotor dilakukan oleh tiga orang guru Biologi. Hasil penilaian kepraktisan oleh guru dikategorikan praktis dengan nilai rata-rata $72,23 \%$.

Tabel 1. Produk Hasil Pengembangan

\begin{tabular}{cc}
\hline Instrumen Ke & Jenis Instrumen \\
\hline 1 & Penilaian Kinerja (Performance) \\
2 & Penilaian Produk \\
3 & Penilaian Proyek \\
\hline
\end{tabular}

Tabel 2. Hasil Validasi Instrumen Penilaian Phsikomotorik

\begin{tabular}{llll}
\hline No & \multicolumn{1}{c}{ Jenis Instrumen } & \multicolumn{1}{c}{ Nilai (\%) } & \multicolumn{1}{c}{ Kriteria } \\
\hline 1 & Penilaian Kinerja (Performance) & 90,3 & Sangat valid \\
2 & Penilaian Produk & 92,2 & Sangat valid \\
3 & Penilaian Proyek & 97,4 & Sangat valid \\
\hline
\end{tabular}

\section{Hasil Validasi Prototipe Instrumen Penilaian Ranah Psikomotor}

Uji validasi merupakan aspek penentu kualitas produk dalam penelitian pengembangan instrumen penilaian psikomotor pada materi sistem pencernaan. Pengembangan instrumen penilaian psikomotor berdasarkan deskripsi hasil validasi instrumen oleh validator menunjukkan bahwa instrumen penilaian yang peneliti rancang dikategorikan sangat valid dengan melakukan perbaikanperbaikan sesuai saran dari validator. Berarti instrumen penilaian psikomotor yang dirancang telah mampu mengukur kinerja siswa sesuai dengan kompetensi yang terdapat dalam kurikulum 2006.

Validitas yang dilakukan pada penelitian ini secara analisis kualitatif. Analisis kualitatif menekankan pada validitas isi dan validitas kontruksi yang dilakukan oleh pakar dan praktisi dengan kriteria sangat valid. Sesuai dengan pendapat Anwar (2009: 45) "strategi mengetahui valid tidaknya butir soal secara isi (content) adalah melalui pertimbangan pakar (judgment experts)" dan dipertegas pula oleh Guion (1977 dalam Surapranata 2005), "validitas isi hanya dapat ditentukan berdasarkan judgment para ahli", serta Riduwan (2009: 97) "untuk menguji validitas konstruk (construct validity), dapat digunakan pendapat ahli (judgment experts)"

Analisis kualitatif dilihat dari aspek materi konstruksi, dan bahasa. Analisis materi bertujuan sebagai penelaahan yang berkaitan dengan substansi keilmuan yang ditanyakan dalam soal dan tingkat kemampuan yang sesuai 
dengan soal. Aspek materi dikategorikan sangat valid karena instrumen penilaian psikomotor yang dikembangkan telah sesuai dengan kompetensi dasar dan indikator, jelas batasan pernyataan dengan jawaban yang diharapkan, kejelasan prosedur kerja/kegiatan, kelengkapan alat dan bahan sesuai dengan kebutuhan, kejelasan soal memungkinkan pengambilan kesimplan yang terperinci, dan mengukur aspek penilaian biologi (pemahaman konsep dan kinerja ilmiah).

Analisis konstruksi bertujuan sebagai penelaahan yang berkaitan dengan teknis penulisan soal. Aspek konstruksi dikategorikan sangat valid karena instrumen penilaian psikomotor yang dikembangkan sesuai kata tanya atau perintah yang menuntut jawaban perbuatan/praktik, rumusan pengalaman belajar jelas, rumusan tujuan pembelajaran jelas, petunjuk pelaksanaan kegiatan jelas, pedoman penskoran jelas, dan tabel, gambar, grafik yang disajikan jelas. Analisis bahasa bertujuan untuk penelaahan soal yang berkaitan dengan penggunaan bahasa Indonesia yang baik dan benar sesuai dengan EYD. Aspek bahasa juga dikategorikan sangat valid karena rumusan kalimat soal komunikatif, menggunakan bahasa yang baik dan benar, penggunaan kalimat pada soal jelas dan tidak menimbulkan penafsiran ganda, dan rumusan soal tidak menggunakan kata-kata yang berlaku setempat.

Menurut validator instrumen penilaian psikomotor pada materi sistem pencernaan sudah valid secara isi karena indikator soal mewakili setiap aspek materi yang dipelajari oleh siswa dan sesuai dengan kompetensi yang terdapat dalam kurikulum 2006. Secara konstruksi instrumen penilaian psikomotor ini juga dinyatakan valid oleh validator karena soal-soal yang membangun instrumen penilaian mengukur setiap aspek berfikir yang dituliskan dalam tujuan pembelajaran. Hal ini sejalan dengan pendapat Surapranata (2005: 53-54)"tes dikatakan memiliki validitas konstruk apabila soal-soalnya mengukur setiap aspek berfikir yang diuraikan dalam standar kompetensi dan kompetensi dasar yang terdapat dalam kurikulum". Berdasarkan hasil uji validitas instrumen penilaian psikomotor yang terdiri atas tes tertulis, kinerja (performance), produk, proyek dapat digunakan guru setelah direvisi.

\section{Hasil Praktikalitas Instrumen Penilaian Ranah Psikomotor}

Hasil penelitian mengenai kepraktisan instrumen penilaian psikomotor menunjukkan bahwa sembilan aspek penilaian memperoleh nilai dengan kriteria praktis. Hasil ini menggambarkan bahwa instrumen penilaian psikomotor telah dinilai dan dipertimbangkan layak untuk digunakan dalam pembelajaran. Dengan demikian instrumen penilaian psikomotor yang dikembangkan telah memenuhi faktor-faktor kepraktisan yaitu kefamiliaran teknik penilaian oleh guru, waktu yang dibutuhkan dalam pelaksanaan, kompleksitas administrasi, kemudahan penskoran, dan kemudahan penafsiran hasilnya.

Menurut Milan, (2001: 68-70) praktikalitas dapat dilihat dalam enam aspek, yaitu: a) kefamiliaran teknik penilaian oleh guru, meliputi keunggulan dan kelemahan serta bagaimana menskor dan menafsirkan hasil kerja siswa. Jika teknik yang digunakan tidak familiar maka akan menimbulkan resiko terhadap waktu dan kesalahan penafsiran, b) waktu yang dibutuhkan dalam pelaksanaannya, mulai dari pembuatan, 
pengerjaannya oleh siswa sampai penskoran dan penafsiran hasil, c) kompleksitas admnistrasi, kemudahan administrasi terlihat dari prosedur yang jelas, sedikit waktu, dan usaha dalam mengelolanya, d) kemudahan penskoran, pemberian skor tergantung pada teknik dan tujuan pembelajaran yang hendak dicapai, e) kemudasan penafsiran, proses penafsiran mudah, jika dapat merancang prioritas penilaian dan bagaimana menggunakan hasilnya dan f) biaya yang digunakan, mulai dari perancangan, pengerjaan, dan penafsiran penilaian. Hal ini sejalan yang dikemukakan Dimyati dan Mudjiono (1996: 144) "faktor-faktor yang mempengaruhi kepraktisan instrumen evaluasi meliputi kemudahan mengadministrasikan, waktu yang disediakan untuk melaksanakan evalusi, kemudahan penskoran, kemudahan interpretasi dan aplikasi”.

\section{KESIMPULAN}

Berdasarkan hasil dan analisis data yang diperoleh dapat disimpulkan bahwa: 1) Telah dihasilkan prototipe instrumen penilaian ranah psikomotor dalam bentuk penilaian kinerja (performance), penilaian produk, penilaian proyek, dan rubrik penilaian dari masing-masing instrumen penilaian ranah psikomotor, 2) Instrumen penilaian psikomotor pada materi sistem pencernaan kelas XI SMA sudah valid, baik dari aspek materi, kronstruksi, dan bahasa, 3) Instrumen penilaian psikomotor pada materi sistem pencernaan kelas XI SMA dikategorikan praktis oleh guru berdasarkan kefamiliaran teknik penilaian oleh guru, waktu yang dibutuhkan dalam pelaksanaan, kompleksitas administrasi, kemudahan penskoran, dan kemudahan penafsiran hasilnya.

\section{UCAPAN TERIMAKASIH}

Penelitian ini adalah bagian dari penelitian dosen pemula yang dibiayai oleh dana DIPA DP2M Kementerian Pendidikan dan Kebudayaan Tahun 2013 dengan nomor kontrak: DIPA 023.04.1.673453/2013. Peneliti mengucapkan terima kasih atas bantuan pembiayaan penelitian ini. Peneliti juga menyampaikan terima kasih kepada validator dan praktisi serta pihak-pihak yang telah membantu terlaksananya penelitian ini.

\section{DAFTAR PUSTAKA}

Anwar, S. (2004). Penilaian Otentik Dalam Pembelajaran Kontekstual Pada Mata Pelajaran Geografi. Jurnal Pembelajaran Volume 27 Nomor 01. Padang: UNP. . (2009). Penilaian Berbasis Kompetensi. Padang: Universitas Negeri Padang Press

Budimansyah, D. (2003). Portopolio Dalam Pengajaran Biologi. Bandung: PT Remaja Rosdakarya.

Depdiknas. (2003). Sistem Penilaian Kelas SD, SMP, SMA, dan SMK. Jakarta: Direktorat Jenderal Pendidikan Dasar dan Menebgah Direktorat Tenaga Kependidikan.

Dimyati dan Mudjiono. (2006). Belajar dan Pembelajaran. Jakarta: Rineka Cipta.

Milan, JH. (2001). Classroom Assessment: Principles and practice for Effective 
Instruction. Los Angeles. Allyn and Bacon.

Muslich, M. (2009). KTSP Pembelajaran Berbasis Kompetensi dan Kontekstual: Panduan bagi Guru, Kepala Sekolah, dan Pengawas Sekolah. Jakarta: Bumi kasara.

Nur, M. (2006). "Penelitian Pengembangan". Makalah disajikan dalam lokakarya Peningkatan Pengetahuan Dosen Melakukan Penelitian Pengembangan. Jurusan Biologi FMIPA Universitas Negeri Padang, Padang 27-29 Juni.

Riduwan. (2007). Belajar Mudah Penelitian untuk GuruKaryawan dan Peneliti Pemula. Bandung: Alfabeta.

Surapranata, S dan Hatta, M. (2007). Penilaian Portopolio: Implementasi Kurikulum 2004. Bandung: PT. Remaja Rosdakarya.

Popham, J. W. (1995). Classroom Assesssment:What Teachers Need to Know. Los Angeles: Allyn And Bacon. 